\title{
Interpupillary distance and convergence in the presbyopic population
}

\author{
Distância interpupilar e convergência \\ na população présbita
}

Celso Marcelo da Cunha1, Renato José Bett Correia²

\begin{abstract}
Objective: To determine the measurements of interpupillary distance (IPD) and ocular convergence in the presbyopic population with corneal reflex pupillometer. Methods: 160 subjects (66 males and 94 females) aged 41 to 85 years have their measurements of IPD done - far and near - by CRP method. Results: The mean age was $55.9 \pm 11.5$ years; the average IPD was $65.02 \pm 2.78$ and $62.47 \pm 3.15 \mathrm{~mm}$ for male and female respectively. Also, the average convergence was $5.00 \pm 0.5 \mathrm{~mm}$. There was a strong direct correlation between the increase in IPD and convergence. Conclusions: This study suggests that the average IPD is slightly smaller in presbyopic female population, and there is variation in the convergence according to the IPD of the subject.
\end{abstract}

Keywords: Refraction; Interpupillary distance: Presbyopia

\section{RESUMO}

Objetivo: Determinar as medidas da distância interpupilar (DIP) e convergência ocular na população présbita com pupilômetro de reflexo corneano. Métodos: Cento e sessenta pacientes, com idades entre 41 e 85 anos, sendo 66 do sexo masculino e 94 do sexo feminino, foram avaliados com medida da DIP longe e de perto com PRC. Resultados: A média da idade foi de 55,9 $\pm 11,5$ anos, a DIP média foi de $65,02 \pm 2,78$ e $62,47 \pm 3,15 \mathrm{~mm}$ para o sexo masculino e feminino, respectivamente. A média da convergência foi de $5,00 \pm 0,5 \mathrm{~mm}$. Houve forte correlação direta entre o aumento da DIP e a convergência. Conclusões: Este estudo sugere que a DIP média é pouco menor na população présbita feminina e que existe variação da convergência de acordo com a DIP do paciente.

Descritores: Refração; Distância interpupilar; Presbiopia

\footnotetext{
1 Oftalmocenter Santa Rosa, Cuiabá, MT, Brazil.

${ }^{2}$ Hospital Geral Universitário, Cuiabá, MT, Brazil.

The authors declare no conflicts of interest
}

Received for publication 31/12/2014 - Accepted for publication 29/04/2015 


\section{INTRODUCTION}

I nterpupillary distance (IPD) is the interval between the centers of the pupils. The location of these centers can be realized in some ways, and the use of corneal reflex is the most commonly used one ${ }^{(1)}$. To measure the IPD special millimeter rules can be used, as those proposed by Gil Del Rio, and the corneal reflection pupillometer (CRP) ${ }^{(1,2)}$. Human nature itself imposes many variations in the size of the IPD, which is related to age, sex, race, etc.

Ametropies are frequent reasons for ophthalmologic appointments $^{(1)}$. The IPD measurement should be part of the refraction exam, assuming fundamental importance whenever one of these cases appear: phorias, tropies, anisometropia, the high ametropies (> 3 spherical diopters), and the users of progressive lenses (PL). Note that some ophthalmologists choose to assign the task of measuring the IPD to the optician.

In Brazilian literature, there are data on the distribution of IPD in the general population, including the child population ${ }^{(1)}$. There were no quotes on this data in presbyopic people, not even of convergence.

\section{MethodS}

A study was carried out at the Ophthalmology Ambulatory of the University General Hospital of Cuiabá and Oftalmocenter Santa Rosa in a prospective way between March and December 2010. 160 presbyopic patients were selected, aged between 41 and 85 years old. The informed consent was clear to all participants, according to the rules of the National Health Council.

The inclusion criteria were: visual acuity better than or equal to 0.7 in both eyes, orthoforic, with normal biomicroscopy, fundoscopy and ocular motility.

Three measures of IPD and three measures to nearsight were carried out by the authors for each patient with CRP Reichert $15020 \AA$.

For statistical analysis, we used the Microsoft Excel 2007 program, along with the "PHStat software", accepting a significance threshold of $5 \%$.

\section{ReSULTS}

Of the 160 patients, $66(41.25 \%)$ were male and 94 $(58.75 \%)$ were female. The average age was $55.9 \pm 11.5$ years.

The minimum IPD found was $54 \mathrm{~mm}$, and the maximum was $72 \mathrm{~mm}$, the average was $65.02 \pm 2.78$ and $62.47 \pm 3,15 \mathrm{~mm}$ for men and women, respectively. The average convergence was 5.00 $\pm 0.5 \mathrm{~mm}$. A Student's $t$-test was performed for average difference, assuming equal variances and significance level of 0.05 . Regarding the average age between men and women, there was no significant difference. Compared to the average of the IPD between the sexes, a significant difference was found; the same happened for convergence.

Figure 1 shows the influence of IPD in convergence with a direct relation between these variables and a correlation coefficient of 0.9 .

Three groups were formed as a result of this correlation, where group 1 corresponded to variations in the IPD from 55 to $60 \mathrm{~mm}$, with average convergence of $4 \mathrm{~mm}$, from 61 to $67 \mathrm{~mm}$ of $5 \mathrm{~mm}$, and from 68 to $72 \mathrm{~mm}$ of $6 \mathrm{~mm}$. The distribution of these groups is shown in Figure 2. The distribution of female patients is shown in Figure 3.

Chart of the dispersion between convergence and IPD.

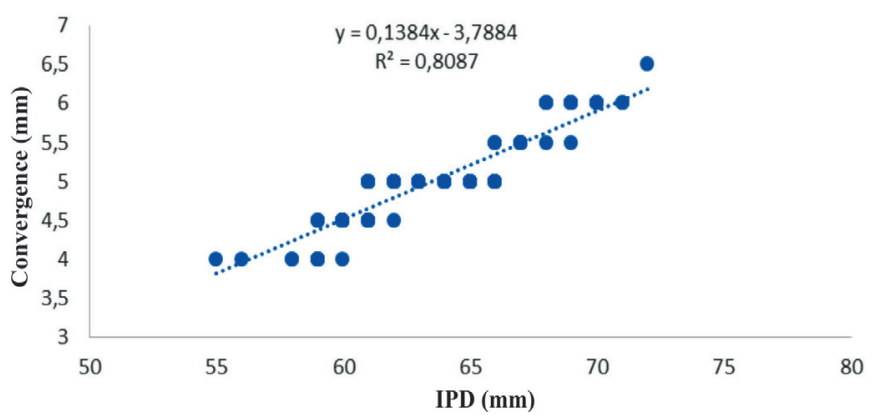

Figure 1: Dispersion between measures of convergence and IPD (in mm).

\section{IPD General Distribuition}
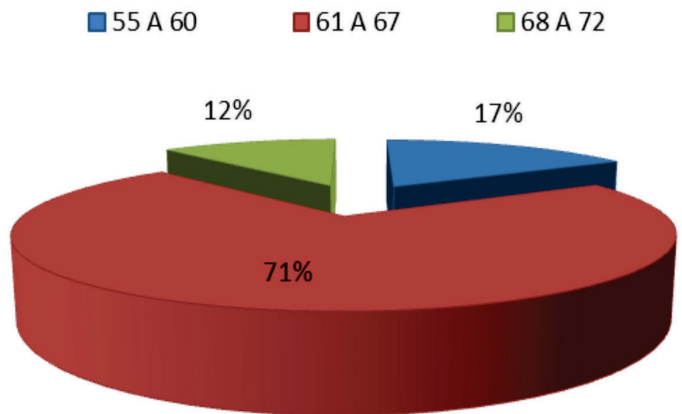

Figure 2: Distribution of patients according to the measure of the IPD for farsight (in $\mathrm{mm}$ ).

IPD Female Distribuition
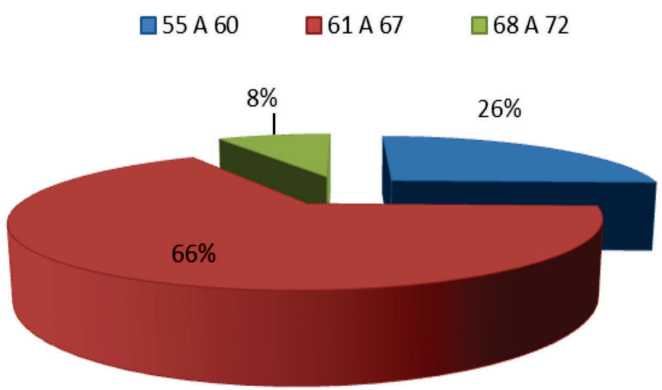

Figura 3: Distribuição dos pacientes do sexo feminino de acordo com a medida da DIP de longe (em mm).

\section{Discussion}

Approximately $50 \%$ of lenses prescribed to patients over 40 years in the US are $\mathrm{PL}^{(3)}$. In Brazil, unofficial data suggest slightly lower percentages of these lenses. It is vital that the markings centers of these lenses match the visual axes of the patients, because the entire distribution of the progression corridor for the near field and areas of nasal and temporal aberrations 
are dependent on its proper centralization ${ }^{(4,5)}$. Most of the conventional PL (those manufactured by molding) present fixed descentration from far to near of $2.5 \mathrm{~mm}$ for each side, but some descenter $2 \mathrm{~mm}$. In customized PL (manufactured with freeform surfacing), the decentralizations can be individualized according to the patient convergence.

Regarding the IPD of the Brazilian population, a study indicated that the average was $64 \mathrm{~mm}^{(1)}$ in the general population. In this study, the average was $65 \mathrm{~mm}$ for males and $62 \mathrm{~mm}$ for females.

There is an idea among the professionals who measure IPD that the convergence for adults is always fixed at $2 \mathrm{~mm}$ on each side. However, this study has proved that it depends on the value of IPD, and geater DIPs make greater convergences. Other factors can interfere with convergence, like the size of the patient's arms and their usual reading distance.

Many patients use conventional PL with descentration of $2.5 \mathrm{~mm}$ for each side. However, it was found in the female population that $34 \%$ of patients showed convergence outside these values, demonstrating that custom PL may be more accurate in the centralization of far and near fields, besides the other advantages resulting from this manufacturing process, like the base curve always available, the adjustments of fields according to the patient's needs, reduction of the induced astigmatism, etc.

Not always the centralization of the pupillary reflex to the nose is symmetrical between the eyes. In Brazil, about $45 \%$ of asymmetry were found in these measures. Therefore, the far and near naso-pupillary distance(NPD) must be measured in PL patients for better centralization ${ }^{(6)}$.

\section{Conclusion}

The results show an average IPD in this presbyopic population of 65 and $62 \mathrm{~mm}$ for males and females respectively, and demonstrate the existing differences in convergence. Therefore, the measures of IPD and far and near NPD are key for a good centralization of PL. Further studies are needed so that data from other regions of Brazil are analyzed.

\section{ACKNOWLEDGMENTS}

To Professor Gilmar J. de Oliveira Júnior for his support in the statistical analysis.

\section{RefERENCES}

1. Roehe DV,Arruda JR Jr.Estudo comparativo entre dois métodos da medida da distância pupilar. Rev Bras Oftalmol. 2008; 67(2):63-8.

2. Gil del Rio E. Algunos detalles sobre la llamada distáncia interpupilar. An Inst Barraquer. 1965; 6:54-79.

3. Novo Karp A. Lenses by the numbers. Lenses and Technology. 2004; 50-4.

4. Jalie M. Ophthalmic lenses and dispensing. 3a ed. Oxford: Butterworth Heinemann, Elsevier; 2008. p 45-6.

5. Monte FQ. Erros de confecção das lentes progressivas e suas manifestações clínicas. Arq Bras Oftalmol. 1984; 47(2): 51-6.

6. Cunha CM, Correia RJ. Fotografia em armação com régua milimetrada, novo método de medida da distancia nasopupilar [Resumo]. In: XIX Congresso Brasileiro de Prevenção da Cegueira e Reabilitação Visual, Salvador, p.123, 2010. Arq Bras Oftalmol. 2010; 73 (4 Supl):52.

Corresponding author:

Celso Marcelo da Cunha

Oftalmocenter Santa Rosa

Av.: Miguel Sutil, 8000. Room 208. Santa Rosa Tower building. Bairro Jardim Mariana, ZIP Code 78040400. Cuiabá, MT.

E-mail: celsomcunha@terra.com.br 